\title{
Determinant of Rural Household Participation in Non-Farm and Level of Generated Household Income from the Activities: The Case of Haramaya Woreda, East Hararghe Zone, Ethiopia
}

\author{
Fami Abdurezak ${ }^{1} \quad$ Lemma Zemedu $^{2} \quad$ Daniel Belay $^{3}$ \\ 1.MSc. Lecturer Department of Agricultural Economics, Bonga University, Ethiopia \\ 2.Ethiopian Institute of Agricultural Research, senior researcher \\ 3.Department of Economics, Ambo University, Ethiopia
}

\begin{abstract}
This study analyzed the determinant of rural household participation in non-farm and level of generated household income from the activities in Haramaya district, Ethiopia using cross-section data. During this study both primary and secondary data were employed Primary data were collected from 196 sample respondents using stratified random sampling. In this study both descriptive and econometric analysis was carried out. Descriptive statistics were applied to characterize the sample households in terms of economic, demographic and institutional factors. Heckman two stages selection model was used for estimation of determinant participation of rural households in non-farm activities and determinant level of income from non-farm activities. The result of factors affecting participation of rural households in non-farm activities indicated landholding size, use of irrigation, livestock holding and distance to nearest market negatively and significantly influenced participation while education, household size and non-farm training significant and positively affects participation of rural household in nonfarm activities. In the result of determinant level of non-farm income shows that landholding size, use of irrigation, livestock holding and distance to the nearest market were significant and negatively affects level of non-farm income while household size and education status were significant and positively influenced level of non-farm income. In generally the study identified the determinant of rural household participation in non-farm activities and determinant level of income from non-farm activities. Therefore, Policy makers should integrate the promotion of non-farm activities in the framework of rural development policies and strategies.
\end{abstract}

Keywords: participation, non-farm activities, household income, heckman two steps selection model

DOI: $10.7176 / \mathrm{JPID} / 58-03$

Publication date: January $31^{\text {st }} 2021$

\section{INTRODUCTION}

In most developing countries, agriculture is the mainstay and the largest economic sector for both its contribution to the GDP and generation of employment. In sub-Saharan African countries, agriculture is the major economic activity accounting for the highest share of the GDP and creates an oversized proportion of employment opportunities (MoARD, 2010; FAO, 2016).

Despite that agriculture is being major source of income and employment in most rural areas in developing countries, it has not been able to produce sufficient food to feed their population due to small ratio of farm land to population (Eshetu and Mekonnen , 2016). As a result, rural households are increasingly earning their income from non-farm activities for his or her livelihood. Haggblade et al., (2010) found that non-farm activities contributed 35-50 percent of rural household income across sub-Saharan African countries. This indicates one possible pathway to induce out of food insecurity problem in developing countries is that the promotion and establishments of nonfarm employments.

In Ethiopia, about $83.9 \%$ of total populations' inhabitants live in rural areas and therefore the main source of their livelihood is agriculture. Agriculture become the second most dominant next to service sector of the country's economy, by providing employment for $80 \%$ of whole labors force and contributes $42.7 \%$ to Gross Domestic Product and 70 percent of foreign exchange earnings (CSA, 2013; NBE, 2013).

However, agriculture within the Ethiopia remains largely subsistence, it's production has not kept pace with population growth, food self-sufficiency, and income required to afford bought-in food has not been fulfilled. Per Abebe (2014) incomes from the farming production are constrained by socio-economic, institutional, resource and environmental factors due to almost all farming system dominated within subsistence smallholder farmers. These factors generally attribute for lower productivity of the agricultural sector, which successively forces farmers to have interaction in non-farm activities so as to enhance their income for survive

Non-farm activities became a vital component of livelihood strategies among rural households in Ethiopia. Evidence from study by Beyene (2008) suggested that non-farm activities can play a vital role in improving the well-being of the rural population. Moreover, since agricultural income is susceptible to different shocks, getting income outside of agriculture is significant for farm households (Yizengaw, 2014). For this reason, the share of non-farm income was increasing in Ethiopia. Within the study of Gagabo (2014) the share of non-farm income 
reported was 33 percent in 2009 in Ethiopia. Ethiopian development strategic plan like growth and transformation plan I and growth and transformation plan II was understood that increasing agricultural product alone cannot reduce poverty and achieve available food security (MOFED, 2010; FDRE, 2015). These plans considered encouraging non-agricultural income generating activities in addition to agricultural activities play an infinite role in breaking vicious cycle of food insecurity and poverty.

Non-farm activities are common among people who live in Eastern hararghe Zone. In keeping with Tefera et al., (2005) 60\% proportion of household participated in non-farm activities in highland of eastern hararghe. At the same time there are also constraints (lack of capital, lack of skill, infrastructure problem and etc) and various factors that tackle households from engaging in non-farm activities in study area. Therefore, identifying the factors affecting participation of rural households in NFA and level of income generated from it is the main issues of this paper.

Ethiopia faces severe land scarcity partially of highlands where population densities became very high and farm sizes became very small. Over half of household in Ethiopia cultivate less than one hectare of land while average household size is approximately five members (CSA, 2012) likewise as in step with MoARD (2010) nearly 55 percent of all smallholder farmers operate less than one hectare. Thus, scarcity of land is a critical bottleneck in Ethiopia and particularly in the study area.

In spite of Agriculture is a predominance of Ethiopian economy, a rapidly growing human population, recurrent droughts and periodic floods, complicated by global climate change that has been accompanied by severe soil and landscape degradation in some regions contributed to a situation of national food insecurity (FAO, 2011). This makes rural labour household not to be used throughout a year in their own farm. As a result, a variety of rural households engage in income generating activities faraway from purely crop and livestock production since its gaining prominent role in rural households' income and food security (Assefa, 2011; Gecho, 2016).

Agricultural sector alone couldn't be serving as a method of improving livelihood, achieving food security and reducing poverty within the country. For this reason, overall participation rate of households in non-farm/offfarm was increasing from 2004 to 2008 in Ethiopia (Sisay, 2010). Rural households increasingly motivated in nonfarm employment so as to extend household income and insure against scarcity of farmland in addition as agricultural production risks (Zerai and Gebreegziabher, 2011). Thus, non-farm activities additionally to farm activities are an alternate source of productive employment to alleviate rural poverty (van den Berg and Kumbi, 2006). However, there have been various factors and constraints that affect participation of rural household in nonfarm enterprise in Ethiopia (Loening et al., 2009).

Even though prior some related works are done on the determinant of rural household participation in nonfarm at country level, still there aren't any empirical findings that are available on the determinant participation in non-farm and level of income from it in Haramaya district. This motivates the study to be conducted on factors affects participation of rural household in non-farm and level of income from it. Therefore, this study was aimed to analyze the determinants of rural household participation in non-farm and level income generated from nonfarm activities within the study area. The study would broaden rural households' understanding of non-farming activities and motivate the agricultural non-participant farmers to actively participate in non-farm activities to boost way of their living standards.

\section{RESEARCH METHEDOLOGY}

\subsection{Description of Study Area}

The study was conducted in Haramaya district. It is one of the 18 woredas of the east Hararghe zone located at the distance of $508 \mathrm{~km}$ from national capital and $18 \mathrm{~km}$ from Harar town in the west direction. It's bordered on the south by Kurfa Chele district, on the west by Kersa district, on the north by Dire Dawa administration council, on the east by Kombolcha district, and Harari National Regional State is within the direction of the southeast. The woreda has 33 rural kebeles (HADARD, 2016). According CSA (2011) Haramaya district has a total population 271,394 of which 138,376 are male and 133, 018 are female.

The altitude of this district ranges from 1400 to 2340 meters above sea level. The entire cultivated land is $38,497 \mathrm{Ha}$. The rainfall of the District is bimodal, erratic and uneven distribution, the short rain occurring between the months of February to May and therefore the long rain occurring between the months of June to September. The mean annual rain fall is $492 \mathrm{~mm}$ ranging from $118-866 \mathrm{~mm}$ and located at $42030^{\prime} \mathrm{E}, 9026^{\prime} \mathrm{N}$. The mean maximum and minimum temperatures are 24 and 9 degree Celsius respectively (HADARD, 2016).

The economic activity of the woreda includes sorghum, maize, and haricot bean, wheat, barley, potato, onion, Khat and other vegetable crops. The most common cash crops for the district are vegetables and Khat (HADARD, 2016). 


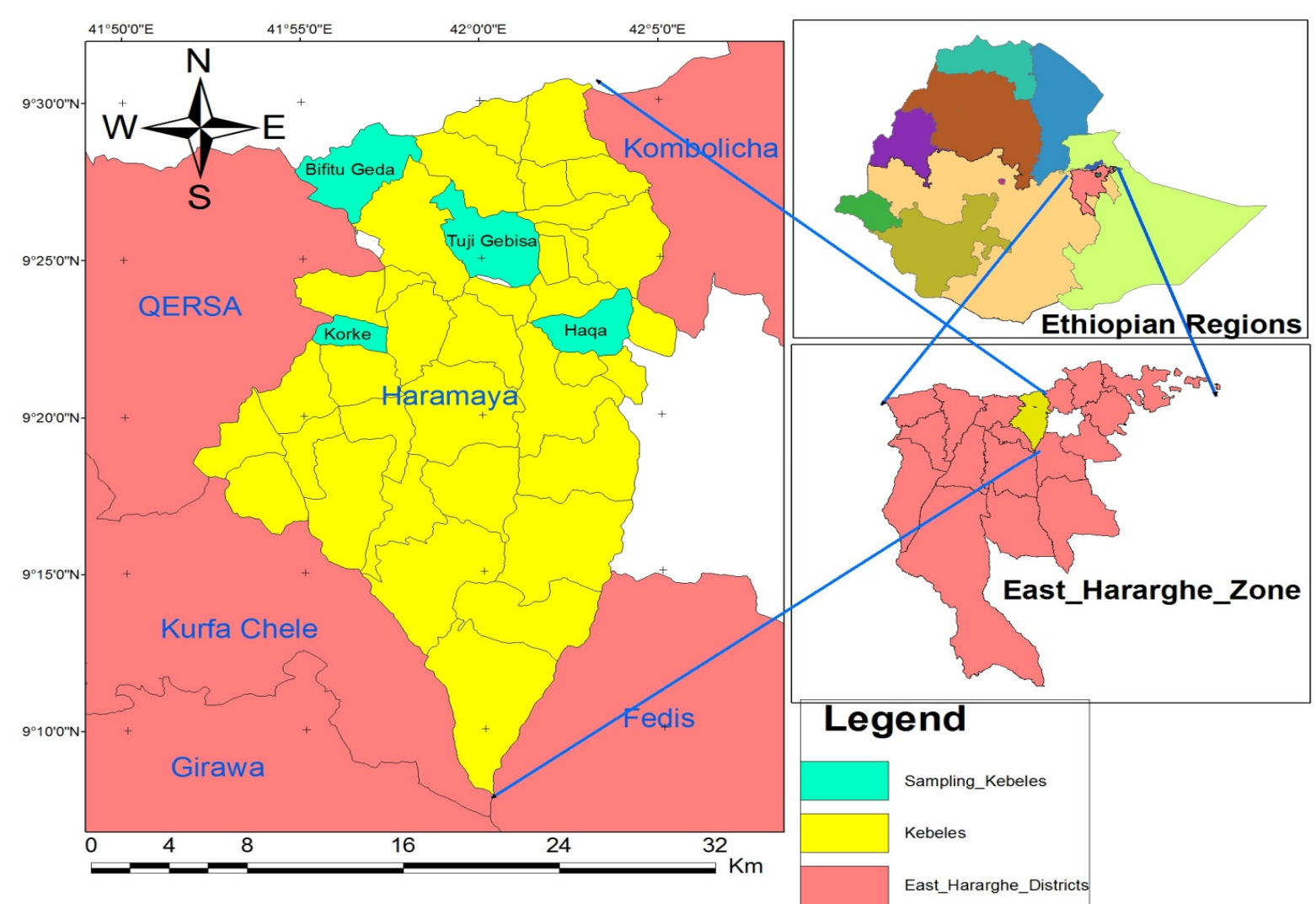

Figure1: Map of EAST Hararghe Zone of Ethiopian Region AND SAMPLing Kebeles of Haramaya DISTRICT.

\subsection{Sources, Types and Method of Data Collection}

The main data collection instruments to collect primary data were used key informant interview, group discussion and also the semi-structured questionnaires. The researcher was used enumerators to collect primary data from rural household by providing training on how to conduct the interview. Before actual data collection had undertaken, a pre-testing questionnaire was conducted so as to revise and adjust those questionnaires. Next, the required data were collected from sample household using semi-structured questionnaire about demographic, economic and institutional factors. The interview was conducting the subject matter of the questionnaire at a given time. Secondary data were gathered from various sources like Agricultural Development Offices of Haramaya Districts, Books, from different published materials about farm and non-farm activities, articles and Journals.

\subsection{Sampling Techniques and Sample Size determination}

In this study, multi-stage sampling procedure was employed. In the first stage, Haramaya district was selected purposively due to the existence of different non-farm activities which rural household could be participated. In the second stage four kebeles were selected randomly from the 33 kebeles. In third stage, households were stratified in to two groups in each kebeles, that is non-farm participant and non-participant, then sample household were selected randomly in each stratum. Equal participant and non-participant were collected in each kebele after using proportional to sample size was used to determine sample size in each kebeles.

In this study the Cochran's formula (1977) were used to determine sample size that is $n=\frac{z^{2} p q}{e^{2}}, \mathrm{q}=1-\mathrm{p}$, where $\mathrm{p}=$ the proportion of household participating on non-farm activity in Haramaya district.

According to Cochran (1977) if the degree of variability is not known, you can assume the maximum variability, which is equal to $50 \%(\mathrm{p}=0.5)$ and taking $95 \%$ confidence level. Macfarlane (1997) also suggested that if there was doubt about the value of $\mathrm{P}$, it is best to take $50 \%$ as it would lead to a larger sample size. In this study, there was no exact number (percent) of farm household who participate in non-farm activities in this district. Therefore, in this study arbitrary maximum variance 0.5 is employed

$n=\frac{(1.96)^{2} * 0.5(1-0.5)}{(0.07)^{2}}=196$ 


\subsection{Method of Data Analysis}

\subsubsection{Descriptive statistics}

Descriptive statistics such as mean, standard deviation, frequency and percentage were used. For a comparison chi-square for dummy variables and t-test for continuous variables were used. And result was presented using tables.

\subsubsection{Econometric analysis}

Heckman selection model (two-step) was employed for analyzing the determinant of participation in non-farm activities and level of non-farm income. Two stages estimation are used under hackman model procedure. In the first stage, a probit is estimated the determinant participation in non-farm work with data from both participants and non-participants, using the estimation result inverse mills ratio is then calculated. In the second stage estimation Heckman selection model procedure is used to identify factor affecting level of income from non-farm activities. In the second stage estimation OLS model can be used on the factor affect level of non-farm income using data from the participant households only while including inverse mills ratio to account selection bias is then undertaken. For the issue of sample selection bias, initially Heckman's two stage estimation technique was employed to estimate both the selection and outcome equations were employed. Heckman two-stage estimation approves the existence of selectivity bias based on selectivity variable (mills lambda). This indicates the advantage of hackman two stage model rather than tobit model (Gebremedhin et al., 2009; Ouma et al., 2010).

Probit model was employed to determine the factors influencing the probability of rural households' participation in nonfarm activity. In this model, the response variable is binary, taking only two values, 1 if the household participate in nonfarm activity, 0 if not. The participation in nonfarm activities is determined by different explanatory variables. This is expressed by

$$
h_{i}=X_{i} \beta_{i}+u_{i}
$$

Where; Household participation $h_{i}$ is dependent variable, $X_{i}$ is explanatory variable, $u_{i}$ is denotes error term. As before, let $h_{i}=1$ if the household participate in nonfarm activities and $h_{i}=0$ if it does not. Now it is reasonable to assume that there is a critical or threshold level of the index, call it $\mathrm{h}^{*}$, such that if $h_{i}$ exceeds $h_{i}^{*}$, the household participate, otherwise it did not. The threshold $h^{*}$, like $h_{i}$, is not observable, but if we assume that it is normally distributed with the same mean and variance, it is possible to evaluate the parameters of the index and obtain some information about the unobservable index itself. This calculation is as follows; given the assumption of normality, the probability that $h^{*}$ is less than or equal to $h$ can be computed from the standardized normal CDF.

$p_{i}=p\left(h_{i}=1 \mid X_{i}=p\left(h_{i}^{*} \leq h_{i}\right)=p\left(Z_{i} \leq \beta_{1} X_{i}\right)=F\left(\beta_{1} X_{i}\right)\right.$

$\mathrm{X}_{\mathrm{i}}$ denotes explanatory variables in equation one, Where $\mathrm{P}\left(\mathrm{h}_{\mathrm{i}}=1 \mid \mathrm{X}_{\mathrm{i}}\right)$ means the probability that an event occurs given the value(s) of the $X_{i}$, or explanatory variable(s) and where $Z_{i}$ stands for standard normal variable, in which, $\mathrm{Z} \sim \mathrm{N}\left(0, \sigma^{2}\right), \mathrm{F}$ is the standard normal cumuative density function as it is written as follows (Green 2005).

$p_{i}^{*}=F\left(h_{i}\right)=\frac{1}{2 \pi} \int_{-\infty}^{X_{i}} e^{-\frac{Z^{2}}{2}} d Z$

Base on the above formula $\mathrm{P}_{\mathrm{i}}{ }^{*}$ can only be observed if the farmer works within the nonfarm or not otherwise cannot be observable. As a result, $\mathrm{p}_{\mathrm{i}}=1$ if $\mathrm{p}^{*}>0$ and $\mathrm{p}_{\mathrm{i}}=0$ otherwise. For the probit estimation models, marginal effects are reported, instead of the raw coefficient, to make interpretation of the coefficients easier.

Heckman selection model estimate level of non-farm income

Estimate determinant level of non-farm income using OLS method may lead to biased result. According to Green (2003) Heckman selection model is appropriate to estimate determinant of non-farm income because it corrects for sample selection bias. The equation is non-farm income present as:

$Y_{i}=\beta_{i} X_{1 i}^{\prime}+\varepsilon_{1 i}$

' $\mathrm{Y}_{\mathrm{i}}$ ' implies non-farm employment income of each household. It is observable for the participants. Yet it is unobservable for the non-participant households. $X_{1 i}^{\prime}$ Is a vector of observable factors that affect the level of nonfarm income and $\varepsilon_{1 i}$ is error term. The selection model equation stated about participation of household within the non-farm activities is explained as follows. Here, the equation indicates that household's participation depends on some value hi* of a latent variable.

$h_{i}^{*}=Z_{1 i} \alpha+u_{1 i}$

Thus, it can be possible to identify the determinant of participation in non-farm activities using selection equation as stated below. 
$h_{i}=\left\{\begin{array}{l}\text { if } h_{i}^{*} \geq 0 \\ 0 \text { if } h_{i}^{*}\end{array}\right.$

With the decision to participate in non-farm work given by $h_{i}=1$ if individuals participated and $h_{i}=0$ otherwise, where $h_{i}$ is a variable indicates participation in NFA, Z is a vector of variables that influence household participation in non-farm activities and ui the corresponding error term. And the outcome equation (intensity of non-farm income equation) is explained as:

$Y_{i}=\left\{\begin{array}{l}\beta_{i} X_{1 i}+\varepsilon_{1 i} \text { if } h_{i}^{*}>0 \\ \text { Unobserved if } h_{i}^{*} \leq 0\end{array}\right.$

$$
\begin{array}{ll} 
& u_{i} \approx N\left(0, \delta^{2}\right) \\
\text { Assuming } & \varepsilon_{1 i} \approx N(0,1) \\
& \operatorname{corr}\left(u_{i}, \varepsilon_{1 i}\right)=\rho
\end{array}
$$

The conditional expected income of individual households who participate in non-farm activities becomes,

$$
\begin{aligned}
E\left\{y_{i} \mid h_{i}=1\right\} & =X_{1 i}^{\prime} \beta_{1}+E\left\{\varepsilon_{1 i} \mid h_{i}=1\right\} \\
& =X_{1 i}^{\prime} \beta_{1}+\rho \phi\left(Z_{1 i}^{\prime} \alpha_{1} / \Phi\left(Z_{1 i}^{\prime} \alpha_{1}\right.\right. \\
& =X_{1 i}^{\prime} \beta_{1}+\rho \lambda
\end{aligned}
$$

If the correlation coefficient $\rho=0$, it shows there is no collinearity problem in estimating or run OLS regression. The term $\rho \phi\left(Z_{1 i}^{\prime} \alpha_{1} / \Phi\left(Z_{1 i}^{\prime} \alpha_{i}\right.\right.$ is known as inverse Mill's ratio which is usually represents by lambda, $\lambda$ and used for captures selection bias.

Before estimation of the model the different tests were employed. The problem of multi-collinearity among the selected explanatory variables was tested using Variance Inflation Factor (VIF).

$\operatorname{VIF}=(\hat{\beta})=\frac{1}{1-R_{j}^{2}} \quad$ Where, $R_{j}^{2}$ is the squared multiple correlation coefficient between $X_{i}$ and the other explanatory variables. Thus, variance inflation factor (VIF) is necessary to check multicollinearity between continuous variable. As $R^{2}$ increase towards 1 , it is a collinearity of explanatory variables. larger the value of VIF indicates the existence of collinear among the variable $X_{i}$. As a rule of thumb if the VIF greater than 10 the variable is said to be highly collinear (Gujarati, 2004).

Contingency coefficient is used to check multi-collinearity of dummy variables and its value ranges between $0-1$, 0 indicate that there is no association between variables, their decision criterion is computed as $C=\sqrt{\frac{X^{2}}{N+X^{2}}}$ Where $\mathrm{C}=$ stands for coefficient of contingency, $\mathrm{X}^{2}=$ is the chi-square random variable and $\mathrm{N}=$ is total sample size of the study. If the value of $\mathrm{C}$ is greater than 0.75 , the variable are said to be collinear. 
2.5. Definition of Variable and Hypothesis

TABLE 1: SUMMARY OF VARIABLES DEFINITION AND HYPOTHESIS

\begin{tabular}{|c|c|c|c|c|}
\hline $\mathrm{NO}$ & Independent Variables Description & $\begin{array}{l}\text { Variables } \\
\text { Code }\end{array}$ & $\begin{array}{l}\text { Dependent } \quad \text { Variable }= \\
\text { Dummy } \quad \text { Non-farm } \\
\text { Activity Participation } \\
\text { (1), } 0 \text { otherwise }\end{array}$ & $\begin{array}{l}\text { Dependent } \\
\text { Income Gariable= } \\
\text { from } \quad \text { Generated } \\
\text { income activities }\end{array}$ \\
\hline 1 & Age of the household head in years & AgeHH & - & - \\
\hline 2 & $\begin{array}{l}\text { Sex of household head (1=male; } \\
\text { otherwise ' } 0 \text { ') }\end{array}$ & $\mathrm{SexHH}$ & $-/+$ & $-/+$ \\
\hline 3 & $\begin{array}{l}\text { Education of the household head }(1= \\
\text { if attended formal education; } \\
\text { otherwise ' } 0 \text { ') }\end{array}$ & EDUC & + & + \\
\hline 4 & Household size in number & HH Size & + & + \\
\hline 5 & Farm experience in years & FRMEXP & - & - \\
\hline 6 & Landholding size in hectare & LH Size & & \\
\hline 7 & Number of livestock in TLU & TLU & & \\
\hline 8 & $\begin{array}{l}\text { Access to Credit services }(1=\text { access } \\
\text { to credit; otherwise ' } 0 \text { ') }\end{array}$ & ACC Credit & + & + \\
\hline 9 & $\begin{array}{l}\text { Dependency ratio in dividing } \\
\text { productive age members by non- } \\
\text { productive age members }\end{array}$ & DEPDRatio & - & - \\
\hline 10 & $\begin{array}{l}\text { Received remittance } \quad(1=\text { if } \\
\text { household } \begin{array}{c}\text { received } \\
\text { otherwise '0') }\end{array}\end{array}$ & REMIT & + & +1 \\
\hline 11 & $\begin{array}{l}\text { Use of irrigation ( } 1=\text { if household } \\
\text { used; otherwise ' } 0 \text { ') }\end{array}$ & USIRRG & - & - \\
\hline 12 & $\begin{array}{l}\text { Distance to the nearest market in } \\
\text { hours }\end{array}$ & DNMRKT & - & - \\
\hline 13 & $\begin{array}{l}\text { Non-farm training }(1=\text { if any } \\
\text { members of household participated; } \\
\text { otherwise ' } 0 \text { ') }\end{array}$ & NFT & + & + \\
\hline
\end{tabular}

\section{RESULTS AND DISCUSSION}

Under subsequent chapter results of descriptive statistics and econometric results was presented and discussed.

\subsection{Descriptive Statistics}

\section{Socio-economic and demographic characteristics of the respondents}

The total number of respondents that were interviewed is 196, comprising of 98 participants in non-farm activities and 98 non-participants. According to descriptive statistics, some variations/differences were observed between those rural households who were participating in non-farm activities and non-participants in terms of demographic, economic and institutional factors. The two groups differ to some extent in sex, education, remittance, irrigation, credit, non-farm training, age, landholding size, livestock owned, household size, dependency ratio, farm experience, distance to nearest market and access to improved agricultural input.

Table 3.1 presents the description of categorical variables through chi-square test; where education, access to credit, remittance, irrigation, improved agricultural inputs and training showed significant difference between nonfarm activities participants and non-participants. Table 3.2 also presents descriptive differences of continuous variables through t-tests between non-farm activity participants and non-participants; where age of household head, landholding size, farm experience, tropical livestock, distance to nearest market and consumption expenditure were found as sources of significant differences.

Table 4.3 and table 4.4 presents the type of non-farm activities and reason for not participating on those nonfarm activities for the non-participants respectively. The major non-farm activities in the study area were petty trade, daily labor, masonry, and carpenter. The major reason for not participating in non-farm activities were lack of initial capital, poor infrastructure, lack of skill and employment opportunity. 
TABLE 3.1: DESCRIPTIVE RESULT FOR CATEGORICAL/DUMMY VARIABLES ON COMPARISON BETWEEN PARTICIPANT AND NON-PARTICIPANT

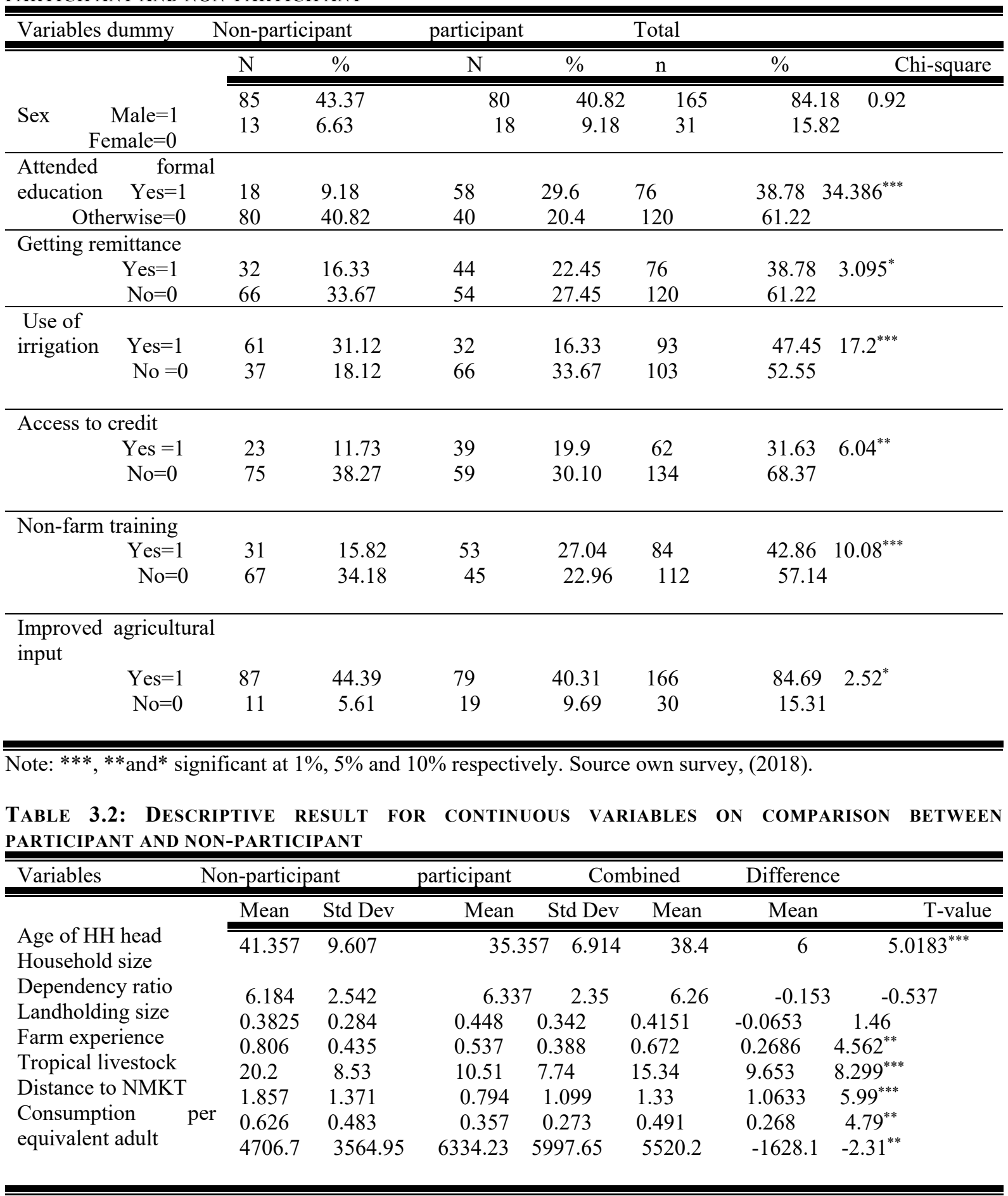

Note: $* * *, * *$ and $*$ significant at $1 \%, 5 \%$ and $10 \%$

Source: own survey, (2018) 
TABLE 3.3: TYPES OF NON-FARM ACTIVITIES

\begin{tabular}{lll}
\hline Types of non-farm activities & Number of household & Percent \\
\hline Petty trade & 49 & \\
& $42.24 \%$ & $4.31 \%$ \\
Broker & 5 & $13.793 \%$ \\
Daily labor & 16 & \\
Masonry & 18 & \\
Carpentry & $15.52 \%$ & \\
& 15 & \\
Others & $12.93 \%$ & \\
& 13 & \\
Total & $11.21 \%$ & \\
& 116 & \\
\hline
\end{tabular}

Source: own survey, (2018)

TABLE 3.4: REASON FOR NOT PARTICIPATED IN NFA

\begin{tabular}{lcc} 
& Number of household & Percent \\
\hline Poor rural infrastructure & 20 & $32.79 \%$ \\
Lack of employment opportunities & 15 & $24.59 \%$ \\
Did not have skill or knowledge & 18 & $29.51 \%$ \\
Did not have initial capital & 27 & $44.26 \%$ \\
Low level of demand for labor & 7 & $11.48 \%$ \\
Others (age, healthy problem, fears and etc) & 11 & $18.03 \%$ \\
\hline
\end{tabular}

Source: own survey, (2018)

\subsection{Econometric results}

Based on heckman selection model, the first step of this econometric result is about the determinants of participation decision analysis while the second step focuses on the determinants level participation measured in amount of non-farm income. The estimation result of Heckman two-stage selection econometric model suggested that there is sample selectivity bias since the inverse mills ratio is statistically significant. The result shows, participation in nonfarm activities has effect on the level of generated income from non-farm activities. And also the negative sign and significance of the IMR shows that there are unobserved factors that are negatively affecting both participation decision and level of non-farm income. Moreover, rho is positive, indicates that unobservable factors are positively correlated with one another

\subsubsection{Determinant for decision of rural household to participate in non-farm activities}

A marginal effect of determinants to participate in non-farm income generating activities is presented in Table 3.5. Household size has positive effect on the probability of participation in non-farm activities; where having one extra person within the household increases participation decision by 5 percent. This might suggest that households with more household size may have the labor power to participate in the nonfarm activities as agricultural activity is seasonal and not sufficient to satisfy their needs. This is often from the fact that higher household size in a limited land that leads to greater surplus of the labor resource and, hence farmers try and seek extra activities out of agriculture for various purpose. This finding is in line with that of Tafesse et al., (2015), Zerai and Gebreegziabher (2011).

Comparing household head attended formal education with others, household head who attended formal education has more $(27 \%)$ probability of participation in non-farm activities than the non-literate household heads family. Thus, non-attended formal education household head may push the household to concentrate only on subsistence and on-farm agricultural activities. This finding is in line with that of Tafesse et al., (2015) and Gecho (2016).

Landholding size has a significant and negative effect on the likelihood of participation in nonfarm activity. That is, as the landholding size of a farm household increase by one hectare, the probability of participating in non-farm activities decrease by 41 percent at 1\% level of significance. The result is consistent with the results reported by Abebe, (2012); Ababbo, and Sawore (2015). The plausible reason for this is that households who have large land size are busy with working on their plot of land. Thus, they are less likely to participate in non-farm activities owing to shortage of time.

Use of irrigation is important factor affecting decision to choose non-farm activities. The probability of participating in non-farm activities for households who used irrigation decreased by 25 percent compared to other households which did not use irrigation at $1 \%$ significance level. Households who use irrigation are less likely to 
engage in nonfarm activities than those are not using it. The reason behind is that irrigation user can produce crops two or more times per year instead of once which would create employment opportunities on their agricultural land. Similar studies suggest that households with access to irrigation are less likely to participate in nonfarm employment (Zerai and Gebreegziabher, 2011; Demie and Zeray, 2015).

Livestock holding were found to behave negative effect on the probability of participation in non-farm activity. The probability of participation in nonfarm activity decreases by 9 percent for a one unit increase of tropical livestock holding at 5 percent probability level. The plausible reason for this result is that livestock enables the farm households to have better chance to earn more income from selling livestock and livestock's product which enables them by increasing purchasing power food during food shortage and relieving liquidity constraint which can able in ensuring household food security. This is similar to the finding of Tefera et al., (2005) and Gecho, (2016) in Ethiopia.

The distance from the nearest market indicated a negative effect on the probability of participate in the nonfarm activities, as the distance from the market increased by 1hours, the probability of non-farm participation of the household declined by 34 percent at 5\% significance level. This indicates households engaged in nonfarm activities have a better access to the nearby market and has an employment opportunity to engage in non-farm. Therefore, households closer to the market were able to participate in nonfarm activities. This finding is in line with that of Assefa (2011) and Tafesse et al., (2015). Travel time required to the nearest main market negatively and significantly influences the household's decision to participate in non-farm activity.

TABLE 3.5: MARGINAL EFFECT ESTIMATES FOR PARTICIPATION IN NON-FARM ACTIVITIES

\begin{tabular}{lrrcc}
\hline variable & $\mathrm{dy} / \mathrm{dx}$ & \multicolumn{1}{c}{ Std. Err. } & $\mathrm{z}$ & $\mathrm{P}>|\mathrm{z}|$ \\
\hline SexHH & 0.08 & 0.13 & 0.6 & 0.549 \\
AgeHH & -0.01 & 0.01 & -1.00 & 0.128 \\
HH size & $0.05^{* *}$ & 0.02 & 2.5 & 0.012 \\
EDUC & $0.27^{* * *}$ & 0.10 & 2.7 & 0.009 \\
REMIT & 0.02 & 0.10 & 0.2 & 0.814 \\
LH size & $-0.41^{* * *}$ & 0.12 & -3.42 & 0.001 \\
USIRRG & $-0.25^{* * *}$ & 0.09 & -2.8 & 0.004 \\
TLU & $-0.09^{* *}$ & 0.04 & -2.25 & 0.029 \\
ACC credit & 0.09 & 0.07 & 1.29 & 0.219 \\
DNMRKT & $-0.34^{* *}$ & 0.14 & -2.43 & 0.016 \\
NFT & $0.18^{*}$ & 0.09 & 2 & 0.058 \\
\hline
\end{tabular}

$* * *, * *$, and $*$ significant at the $1 \%, 5 \%$, and $10 \%$ level, respectively

(*) dy/dx is for discrete change of dummy variable from 0 to 1

\subsubsection{Determinant for the level of income from non-farm activities}

Table 3.6 presents the result of Heckman second stage model, where determinants for the level of income generated from non-farm activities were identified. Household size has significantly and positively influenced the level of non-farm income at $1 \%$ significance level. The coefficient shows that the level of non-farm income generated by rural household increases by 134.55Birr with increase in household size by one extra persons. The presence of large number of economically active members in the household improves the capacity and ability of household to extend level of non-farm income. This enables to generate high non-farm income than those households constrained by availability household members. This is in line with the results reported by Sisay (2010). Household with large number of individuals increases the level of income from nonfarm activities.

Education status of household heads affects level of non-farm income positively and significantly. The coefficients of non-farm income increase by Birr 914.01 as household head being attended formal education, all other factors remain constant. Education improves the ability of searching out information about income generating activities and educated household head also has better skill, experience, knowledge than the noneducated households. It determines the capability of finding a job. Thus, education is a fundamental instrument in providing necessary skills to the farmers which enable them to increase an alternative income generating sources than illiterate ones. This finding is in line with that of Weldegebriel (2015).

Landholding size is an important variable having significantly negative effect on level of nonfarm income in the study area. It was significant at $1 \%$. The coefficient implies that with all other factors kept constant, the level of non-farm income generated by rural household decreases by 108.62 Birr with increase in size of landholding by one hectare. Increase in size of cultivated land increases the amount of production to be harvested. Therefore, those farmers who cultivated more become in a better position than those who cultivated less which leads household with small landholding/cultivated land to be generated more income from non-farm activities than households with large land size. This is consistent with the results reported by Lemi (2009).

The effect of irrigation use on the level of non-farm income is negative and significant at $1 \%$ significance levels. The coefficients of non-farm income decrease by Birr 510.35 as households become user of irrigation, 
citrus paribus. This result indicates that using irrigation increases the vegetable and non-vegetable farm income rather than non-farm income among the sample households. This might be because of the fact that participation in irrigation would improve agricultural production and productivity. There is also no spare time to engage in nonfarm income as the irrigation user households are occupied the whole year in agricultural activities.

TABLE 3.6: HECKMAN SELECTION MODEL (TWO-STEP) ESTIMATES LEVEL OF NON-FARM INCOME

\begin{tabular}{lrrrr}
\multicolumn{1}{l}{ Variables } & Coef & Std. Err. & $\mathrm{T}$ & $\mathrm{P}>|\mathrm{z}|$ \\
\hline nonfarm income & & & & \\
sexHH & 43.40 & 63.13 & 0.69 & 0.493 \\
ageHH & -176.52 & 320.08 & -0.55 & 0.582 \\
HH size & $134.55^{* * *}$ & 45.13 & 2.98 & 0.003 \\
EDUC & $914.01^{* * *}$ & 260.56 & 3.51 & 0.001 \\
REMIT & 44.00 & 45.34 & 0.97 & 0.333 \\
LH size & $-108.62^{* * *}$ & 29.32 & -3.71 & 0.000 \\
USIRRG & $-510.35^{* *}$ & 232.11 & -2.2 & 0.029 \\
TLU & $-242.25^{* *}$ & 105.36 & -2.3 & 0.023 \\
ACC credit & 136.86 & 321.69 & 0.43 & 0.671 \\
DNMRKT & $-100.26^{* * *}$ & 37.06 & -2.71 & 0.007 \\
cons & 512.61 & 428.13 & 1.2 & 0.233 \\
\hline Mills lambda & $-800.56^{* * *}$ & 225.91 & -3.54 & 0.000 \\
\hline
\end{tabular}

$* * *, * *, *$ significant at the $1 \%, 5 \%$, and $10 \%$ level, respectively

Livestock holding found to have significant and negatively influence on the level of non-farm income. The coefficient of the variable shows that as the household gets one more TLU the level of income from non-farm activities decreases by Birr 242.25. This indicates that households with larger livestock holding may have the opportunity to plough at any time with minimum labor cost, especially for oxen this may lead to improved income from household farm crop production rather than non-farm income. On the other hand, it can serve as a critical input in farm operations as it enhances production and is also an important source of capital through which considerable income is generated.

Distance to the nearest market has a negative and significant effect on level of non-farm income. The coefficient of the variable shows that as the distance to the nearest market increases by one hour the level of income from non-farm activities decreases by 100.26 Birr. Households residing in places far from nearest markets could get less income from non-farm work because of higher transaction costs. This is in line with the result reported by Demissie and Legesse (2013).

\section{CONCLUSIONS AND RECOMMENDATIONS}

An econometrics analysis, Heckman two-stage model identified the determinants of participation in non-farm activity and level of income from it in the study area. The probability of rural households participation decision in non-farm activity were influenced by household size, education, irrigation, landholding size, livestock holding, distance to nearest market and non-farm training. Whereas household size, education status, landholding size, irrigation, livestock holding and distance to nearest market influenced intensity of income from non-farm activities.

Based on the findings of this research, the following major policy implications can be extracted that can help to design appropriate intervention mechanisms:

Landholding size has negative and significant effect of on the probability of participation in non-farm activities and level of income from it. This indicates rural household who has large land size have enough income from farm activities and they did not want to engage in non-farm activities. Hence, extension services and improved agricultural input provision to such households should be promoted to enhance their farm income.

Educational status of household head significantly and positively influenced participation and level of income from non-farm activities. This implies education may expand probability to employ in non-farm activity and enhances high income earning capacity of farmers from non-farm activities. Therefore, rural households should be equipped with basic formal education as it improves skill and knowledge of farmers to diversify their household income.

Distance to nearest market affects probability of participation in non-farm activities and level of income from it negatively. Therefore, Local market should expand in the study area in order to reduce the entry barriers and facilitate easier access to nonfarm activities.

Entrepreneurial training on non-farm activities is one of the factors that significantly and positively affect the probability of rural household participation in nonfarm activities. As a result, provision of such training for rural household is vital be it by government or NGO and even by cooperatives organization.

Finally, there should be policy and program intervention to facilitate and stimulate participation of rural household in non-farm activities due to non-farm activities has play a great potential role for increasing rural employment and improving wellbeing since the agricultural sector alone cannot have a position to create additional 
employment opportunities and provide adequate income to sustain the livelihood of the rural household.

\section{REFERENCE}

Aababbo, Y. E. and Sawore, A.M. (2015). Assessing determinant factors of income diversification among rural farm households in Ethiopia: the case of Leemo and Anileemo Districts, Hadiya Zone, South Nation Nationalities People Region. International Journal of Science and Research, ISSN (Online): 2319-7064

Abebe, G.G. (2014). Off-Farm Income and Technical Efficiency of Smallholder Farmers in Ethiopia Year of publication: 2014 No: 862 ISSN 1401-4084

Assefa, F. (2011). Determinants of rural household's participation in non-farm activities and its effect on income distribution: The case of Wonchi district in central Oromia, Haramaya University

Beyene, AD. (2008). Determinants of off-farm participation decision of farm households in Ethiopia. Agrekon, Vol 47, No 1

CSA (2011). Population size by age, area and density by region, zone and woreda. Demographic and health survey. Statistical Agency Report, Addis Ababa, Ethiopia.

CSA (2013). "Annual Agriculture Sample Survey of Farm Management Practice Report," Addis Ababa, Ethiopia

Cochran, WG. (1977). Sampling Techniques, 3rd edition. New York: John Wiley and Sons.

Demie, A and Zeray, N. (2015). Determinants of Participation in the Rural Nonfarm Economy in Eastern Ethiopia: Journal of Economics and Sustainable Development, ISSN 2222-1700 (Paper) ISSN 2222-2855 (Online) Vol.6, No.23, 2015

Demisse, A. and Legesse, B. (2013). Determinants of income diversification among rural households: The case of smallholder farmers in Fedis district, Eastern hararghe zone, Ethiopia. Journal of Development and Agricultural Economics, 5(3): 120-128.

Eshetu, F. and Mekonnen, E. (2016). Determinants of off farm income diversification and its effect on rural household poverty in Gamo Gofa Zone, Southern Ethiopia; Journal of Development and Agricultural Economics, Vol. 8(10), pp. 215-227,

FAO (2016). Agriculture in Sub-Saharan Africa: prospects and challenges for the next decade. FAO Agricultural outlook 2016-2025

FAO (2011). Independent evaluation of the programmes and cooperation of the food and agriculture organization of the united nations in Ethiopia

FDRE (2015). Federal democratic republic of Ethiopia; The Second Growth and Transformation Plan (GTP II) (2015/16-2019/20): National Planning Commission, Addis Ababa

Fufa, M. (2015). Factors responsible for income diversification among rural households in Agafa District, Bale Zone, Oromia National Regional State, Ethiopia. Haramaya University, Haramaya, Ethiopia.

Gagabo, T.Y. (2014). Analyzing the determinants and the effects of income diversification in rural Ethiopia. The Hague, Netherlands

Gebremedhin, B., Jalata, M. and Hoekstra, D. (2009). Smallholders, institutional services, and commercial transformation in Ethiopia. Journal of Agriculture Economics, 40:773-787. DOI: 10.1111/j.15740862.2009.00414.x

Gecho, Y. (2016). Rural Farm Households' Income Diversification: The Case of Wolaita Zone, Southern Ethiopia. International Journal of Sustainable Development Research, 2 (2): 6-17.

Green, H.W. (2005). Econometric Analysis: Fifth Edition. New York University Macmillan Publishing Company. Greene, H.W. (2003). Econometric Analysis. Prentice Hall, New Jersey.

Gujarati, D.N. (2004). Basic Econometrics, 4th Edition. New Delhi, Tata McGraw-Hill Publishing Company Limited.

HADARD (2016). Geographical and location of Haramaya district. Unpublished manuscript

Haggblade, S., Hazell, P. and Reardon, T. (2010). The Rural Nonfarm Economy: Prospects for Growth and Poverty Reduction. World Development, 38(10):1429-1441

Hailemariam, A., Alayu, S. and Teller, C. (2011). The National Population Policy (NPP) of Ethiopia: Achievements, Challenges and Lessons Learned, 1993-2010. The Demographic Transition and Development in Africa, 303-321.

Lemi, A.(2009). Determinants of Income Diversification In Rural Ethiopia: Evidence From Panel Data: Ethiopian Journal of Economics, 18(1). doi:10.4314/eje.v18i1.59930

Loening, J., Rijkers, B. and Söderbom, M. (2009). Nonfarm Microenterprise Performance and the Investment Climate: Evidence from Rural Ethiopia, World Bank Washington Dc, USA.

Macfarlane, SB. (1997). Conducting a Descriptive Survey: 2. Choosing a Sampling Strategy. Trop Doct, 27(1): $14-21$.

MoARD (2010). Ethiopia's Agriculture Sector Policy and Investment Framework: Ministry of Agriculture and Rural Development Ten-year Road Map (2010-2020).

MoFED (2010). The Federal Democratic Republic of Ethiopia Growth and Transformation Plan (GTP) 2010/11- 
2014/15. Retrived November 10, 2012 from https://www. Mofed.gov.et/ English/resources/documents/national

NBE (2013). "Annual Report," Addis Ababa, Ethiopia,

Ouma, E., Jagwe, J. Obare, G.A. and Abele, S. (2010). Determinants of smallholder farmers' participation in banana markets in Central Africa: the role of transaction costs. Agricultural Economics, 41:111-122. doi: 10.1111/j.1574-0862.2009.00429.x

Sisay, A.W. (2010). Participation into Off-farm Activities in Rural Ethiopia: who earns more? MA Thesis, Erasmus University, Hague, Netherland.

Tafesse, A., Balta, A. and Weldeyohannes, D. (2015). Small Holder Farmers' Participation in Non-Farm Activities: Evidence from Humbo District, Southern Ethiopia. Journal of Poverty, Investment and Development, ISSN 2422-846X An International Peer-reviewed Journal, Vol.7

Tefera, T. L., Perret, S. and Kirsten, J. F. (2005). Diversity in Livelihoods and Farmers Strategies in the Hararghe Highlands, Eastern Ethiopia. International Journal of Agricultural Sustainability, 2, 133-146

Van den berg, M. and Kumbi, G.E. (2006). Poverty and the Rural Nonfarm Economy in Oromia, Ethiopia. Agricultural Economics, 35, 469-475.

Weldegebriel, Z.B. (2015). Rural Non-Farm Diversification in Ethiopia: What Determines Participation and Returns?

Yizengaw, B. (2014). Determinants of Household Income Diversification and Its Effect on Food Security Status in Rural Ethiopia: Evidence from Ethiopia Longitudinal Rural Household Survey, Addis Ababa University, Addis Ababa, Ethiopia

Zerai, B and Gebreegziabher, Z. (2011). Effect of Nonfarm Income on Household Food Security in Eastern Tigrai, Ethiopia: An Entitlement Approach; Food Science and Quality Management ISSN 2224-6088 (Paper) ISSN 2225-0557 (Online) Vol 1 